\title{
Need for a continuing education program for toxoplasmosis control
}

\section{Katia Denise Saraiva Bresciani ${ }^{1, ~ *}$, Daniel Fontana Ferreira Cardia ${ }^{2}$, Lucilene Granuzzio Camossi $^{3}$, André Luiz Baptista Galvão ${ }^{2}$, Amanda Leal de Vasconcellos ${ }^{2}$, Rodrigo Rabelo dos Santos $^{2}$, Thais Rabelo dos Santos ${ }^{2}$, José Antonio Soares ${ }^{4}$}

${ }^{1}$ Faculdade de Medicina Veterinária de Araçatuba, UNESP, Araçatuba, São Paulo. bresciani@fmva.unesp.br

${ }^{2}$ Faculdade de Ciências Agrárias e Veterinárias, UNESP, Jaboticabal, SP

${ }^{3}$ Faculdades de Medicina Veterinária e Zootecnia, UNESP, Botucatu, SP

${ }^{4}$ Faculdades Integradas de Itapetininga, FKB, Itapetininga, SP

\section{Email address:}

bresciani@fmva.unesp.br(K. D. S. Bresciani)

\section{To cite this article:}

Katia Denise Saraiva Bresciani, Daniel Fontana Ferreira Cardia, Lucilene Granuzzio Camossi, André Luiz Baptista Galvão, Amanda Leal de Vasconcellos, Rodrigo Rabelo dos Santos, Thais Rabelo dos Santos, José Antonio Soares. Need for a Continuing Education Program for Toxoplasmosis Control. Education Journal. Vol. 2, No. 4, 2013, pp. 114-118. doi: $10.11648 /$ j.edu.20130204.12

\begin{abstract}
The Toxoplasma gondii infection is very important from the point of view of public health and affects almost all homeothermic animal species, including birds and mammals. In this study, thirty teachers from elementary schools in the northwest area of the state of São Paulo, Brazil, were interviewed about toxoplasmosis. Their students frequented of first to fourth series of the fundamental teaching. The questionnaire with closed questions were: 1) is the cat the main transmitter of toxoplasmosis in humans?; 2) If the cat can transmit toxoplasmosis, how happens?; 3) "If the dog can transmit toxoplasmosis, how happens?"; Is there any other way to acquire toxoplasmosis?; If there are other means of transmission, which can be? After this stage, lectures of short duration were supplied about this disease and reapplied the interview form. The data were analyzed with base in descriptive statistics. We found that there was an assimilation of the concepts on the control of toxoplasmosis by the teachers. In conclusion, there is the need of implanting one continuing education program for the community in general directed to the improvement of basic concepts of toxoplasmosis control.
\end{abstract}

Keywords: Toxoplasma gondii, Education, Prevention

\section{Introduction}

Coccidian protozoan, Toxoplasma gondii belonging to the Phylum Apicomplexa (Kawazoe, 2002) causes a zoonosis of worldwide distribution (Rey, 2008).

The most common clinical in the acute phase of this zoonosis is lymphadenopathy as well fever, malaise, night sweats, myalgia, maculopapular rash and lymphocytic atypia (Bonametti et al., 1997).

This coccidian can cause behavioral alterations (Lafferty, 2005; Yolken et al., 2001) and if the the woman acquires the toxoplasmosis during pregnancy, the congenital form of the disease can occur (Hung et al., 2007).

Results of the congenital toxoplasmosis program in Londrina, Paraná, Brazil, demonstrated a reduction in the number of pregnant women and children sent to referral services for the treatment of toxoplasmosis. Moreover, the definition of protocols results in the standardization of care and safety for decision making by the team of health care for pregnant women (Mitsuka-Breganó, 2009).

Many cases of reactivation of this disease are associated with Acquired Immunodeficiency Syndrome AIDS (Bachmeyer et al. 2006; Jones and Dubey, 2012).

In the United States, toxoplasmosis is the second major foodborne illness, being responsible for hospitalization and even death, both in urban and rural areas (Dubey et al., 1998; Jones and Dubey, 2012).

Considering the relevance of the degree of amount of information held by the teachers (educators) in the municipal fundamental schools, we did this study with the goal to evaluate the degree of knowledge of the teachers from elementary schools about toxoplasmosis, as well 
verifying after the accomplishment of educational lectures, the assimilation of the content supplied by these teachers.

\section{Main Body}

\subsection{Material and Methods}

In this study, thirty teachers from elementary schools in the northwest area of the state of São Paulo, Brazil, were interviewed about toxoplasmosis. Their students frequented of first to fourth series of the fundamental teaching. In treating of the education degree, $6,66 \%$ of the teachers had the complete medium teaching, 8,33\% had incomplete superior level and $85,00 \%$ were graduate.

The questionnaire with closed questions were: 1) is the cat the main transmitter of toxoplasmosis in humans?; 2) If the cat can transmit toxoplasmosis, how happens?; 3) "If the dog can transmit toxoplasmosis, how happens?"; Is there any other way to acquire toxoplasmosis?; If there are other means of transmission, which can be?

After this stage, lectures of short duration were supplied about this disease and reapplied the interview form. The data were contained and analyzed with base in descriptive statistics.

\section{Results and Discussion}

Before the lectures, among the 30 teachers interviewed, 27 incriminated cats as the main transmitter of toxoplasmosis to humans. After the lecture, the profile of responses changed, with 28 of the participants said that the cat was not the main transmitter and only two teachers didn't know the answer (Figure 1).

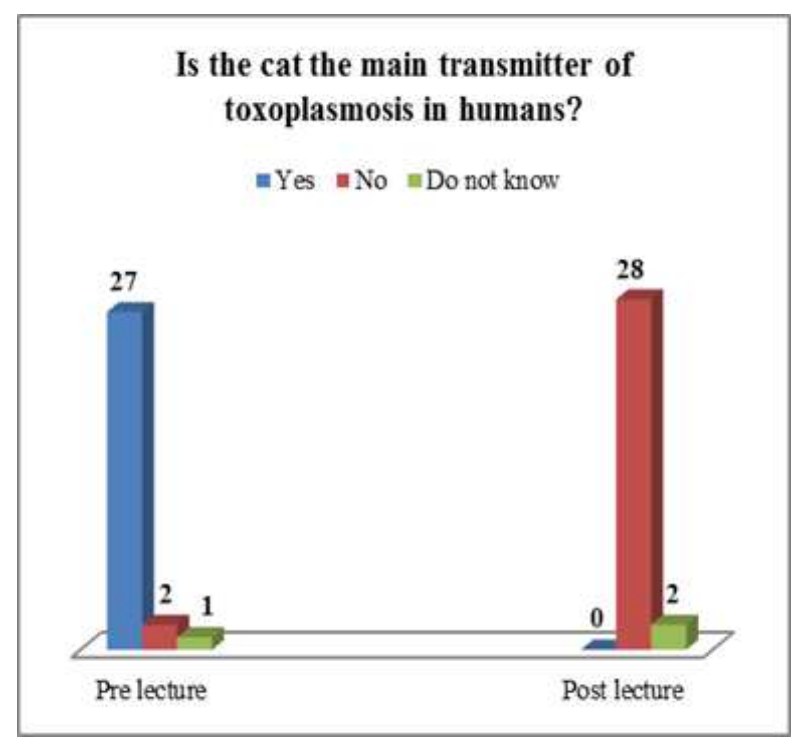

Figure 1. Number of respondents in the first question, pre and post lecture..

The felines, definitive hosts of T. gondii, can eliminate fecal oocysts, evolutionary forms improved by natural selection to support environmental adversities and can be highly infectious for several species of hosts.

It is important to pay attention to these peculiarities of feline behavior and also emphasize that the oocysts are eliminated by these definitive hosts, but need to stay in the environment for at least one day, under certain conditions of temperature and humidity and sporulate to become infective.

Direct contact with this host is irrelevant in the epidemiological chain of the disease due to their habit of licking, and this promotes a mechanical removal of oocysts, preventing sporulation in its pelage. So the environmental control becomes more relevant and effective in preventing the occurrence of this disease in humans, once the oocysts remain viable in the soil for up to 18 months, depending on the temperature, humidity and exposure to sunlight (Frenkel et al., 1975).

The cats are probably the main sources of environmental contamination, because, when infected, release large quantities of oocysts, allowing the continuity of the parasite biological cycle. It is estimated that only in one evacuation about 10 to 100,000 oocysts per gram of faeces can be eliminated (Tenter et al., 2000; Rey, 2008).

This coccidia is present in nature in three evolutionary forms: oocysts, which form up to four sporozoites inside; tachyzoites, proliferative form and tissue cysts containing bradyzoites (Dubey et al., 1998; Garcia, 2007).

The intermediate hosts, humans and animals, can acquire the disease mainly by eating raw or undercooked meat, infected with tissue cysts, as well by the consumption of raw vegetables and water contaminated with oocysts (Garcia, 2007). Tachyzoites of T. gondii can be acquired by consuming unpasteurized milk, eggs, blood transfusion, semen, organ transplantation, laboratory accidents with biological material and by transplacental via (Dubey, 1986; Dubey et al., 1990; Dubey, 1994; Bonametti et al., 1997; Tenter et al., 2000; Kawazoe, 2002; Rey, 2008).

In answer to the second question, before the lecture, 13 of the teachers didn't know, only four mentioned the transmission by feaces newly eliminated, four argued that this happened through the urine and nine indicated the transmission through the faeces maintained for days in the environment. After guidance made in the lecture, the 30 participants emphasized that this occurred because of the permanence of fecal contents into the environment, as can be observed in Figure 2 . 


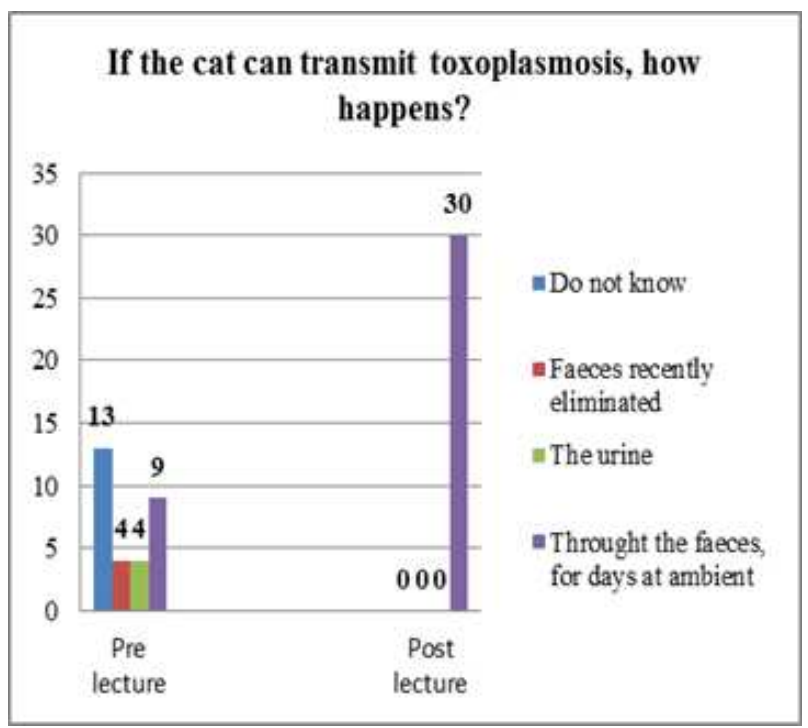

Figure 2. Number of respondents in the secondt question, pre and post lecture.

Regarding the question, if the dog transmit toxoplasmosis and how it occurs, it became evident that 15 ignored the response, 10 responded through the feces, urine and secretions, four of them appointed the contact with the animal's coat and only one said no. After the lecture, 29 teachers said that the dog does not transmit directly to T. gondii infection (Figura 3).

Regarding the question, if the dog transmit toxoplasmosis and how it occurs, it became evident that 15 ignored the response, 10 responded that the dog transmitted through the feces, urine and secretions, four said that was by contact with the animal's coat and only one said no. After the lecture, 29 teachers said that the dog does not transmit directly the $\mathrm{T}$. gondii infection (Figure 3).

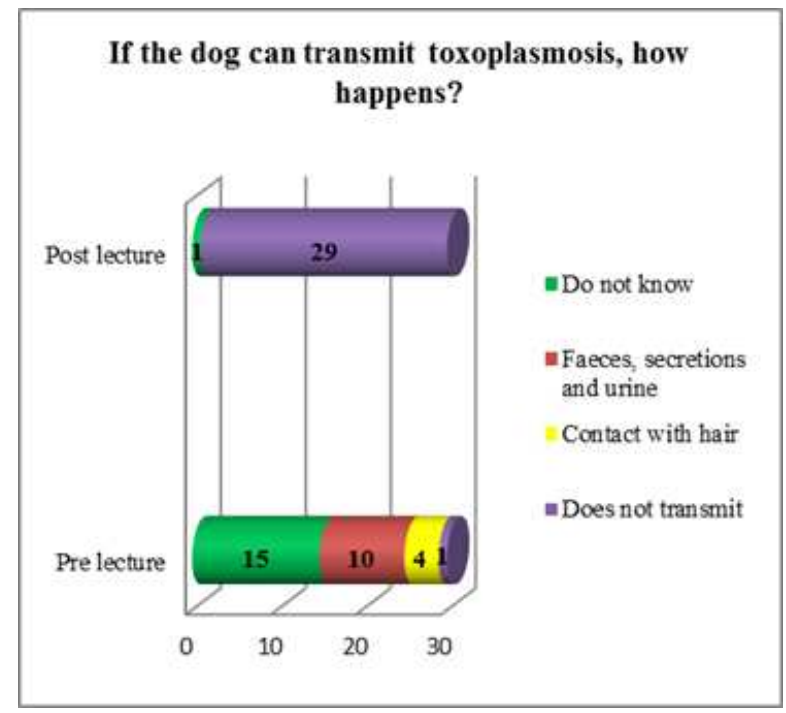

Figure 3. Number of respondents in the third question, pre and post lecture.
During the lecture, it was clarified that the dog doesn't eliminate evolutionary forms (oocysts) of $\mathrm{T}$. gondii in the faeces. The dog can be involved in the mechanical transmission of the infection by Toxoplasma gondii and in spite of not being the definitive host, it has an epidemiological role in this disease (FRENKEL; PARKER, 1996; LINDSAY et al.,1997, SCHARES et al., 2005).

Interesting to note is that after the primary experimental infection of oocysts and tachyzoites of $\mathrm{T}$. gondii in female dogs, this parasite was detected in samples of saliva, milk and urine (BRESCIANI et al., 2001).

At the beginning of the work, 11 respondents said that there could have other forms of transmission of toxo

plasmosis, three said no and 16 did not know about this issue. After interacting with our research group, it was found that almost all of the respondents (29) said that were other means of transmission (Figure 4).

Humans and animals should not consume raw or undercooked meat, unpasteurized or not boiled dairy products, water without being treated and poorly washed fruits and vegetables (Tenter et al., 2000; Monteiro, 2010).

Individuals that have less careful with their hygiene, proper washing of fruits, vegetables and cooking of meat products, thus, having a higher risk of acquiring this disease (Okusaga et al., 2011).

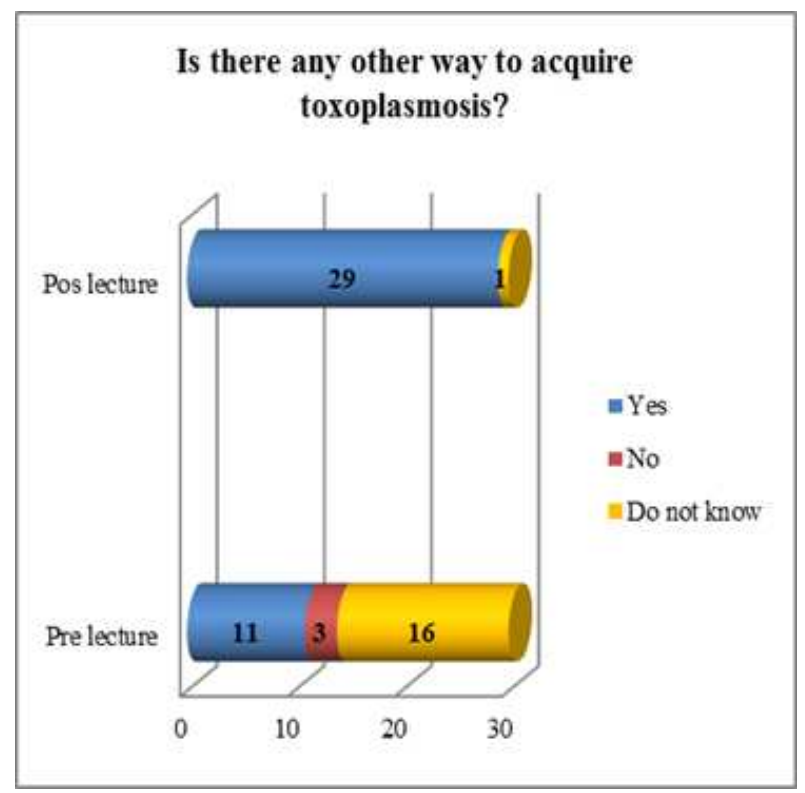

Figure 4. Number of respondents in the fourth question, pre and post lecture.

Before our talk, only one teacher responded that through uncooked meat could be the transmission, 10 did not know and 19 pigeons incriminated. At the end of the study, 29 of these educators reshaped their view, stating that this protozoan infection occur by undercooked meat 
or raw (Figure 5).

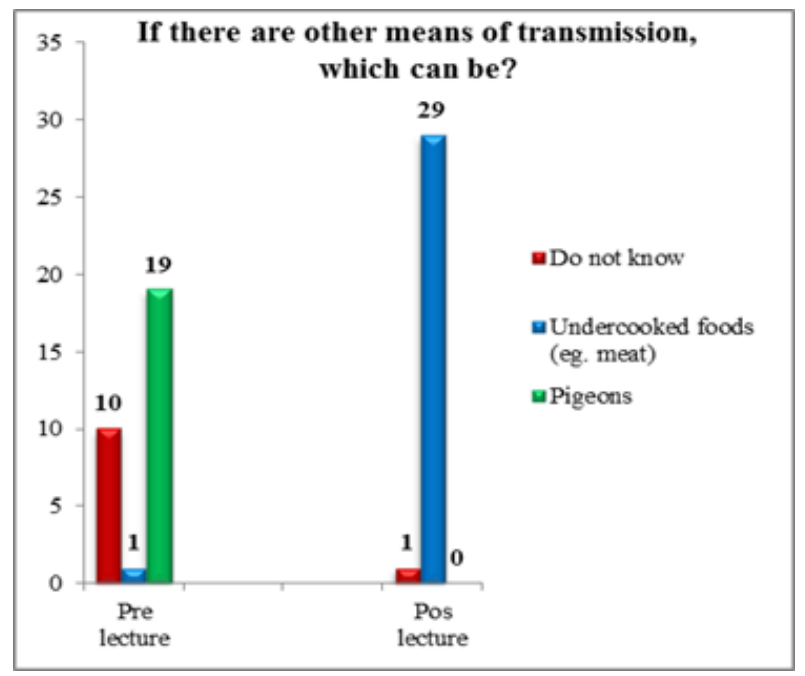

Figure 5. Number of respondents in the fifth question, pre and post lecture.

In relation to the resistance of the cysts in meat, it is believed that they do not resist the processes of salting and heating (above $55^{\circ} \mathrm{C}$ for more than two minutes) used in the preparing of processed meat (Dubey, 1994).

Meat products from ovine and swine are more contaminated with this parasite cysts, and these are rarely found in bovine (Jones and Dubey, 2012).

We interviewed 85 teachers of municipal elementary schools from Araçatuba, São Paulo, Brazil and the participation of cats in toxoplasmosis transmission was known by $92.94 \%$ (79/85), of which $82.35 \%$ (70/85) did not know the transmission routes. The dog was considered the disseminator of this disease by $80.00 \%$ $(68 / 85)$ interviewees, and only $4.71 \%$ (4/85) cited ingestion of meat products as a route of $\mathrm{T}$. gondii transmission, while $67.06 \%(57 / 85)$ did not know about this issue[1].

One hundred and thirty four elderly people were interviewed, using individual questionnaires. When questioned about toxoplasmosis, 78.36\% (105/134) did not know the meaning of the term, and $86.57 \%(116 / 134)$ were ignorant of the means of dissemination. The results demonstrated the need for educational campaigns about the control of parasitical zoonoses.[2].BRESCIANI et al 2012

In the dogs, does not occur the phase enteroepitelial $\mathrm{T}$. gondii and these are infected by ingesting oocysts or tissue cysts. Thus, the coprophagy should be prevented and recommend the providing products or meat cooked rations marketed. Attention should be paid to the elimination of paratenic hosts, such as flies and cockroaches, so as to avoid contact with soil or sand which may be contaminated with feces of cats attending to the daily cleaning of the litter box felines to reduce environmental contamination (Greene, 1990, Lappin,
2004).

Oocysts that are shed by cats into the environment have caused several outbreaks of this disease in humans (Teutsch et al., 2006). We evaluate the presence of T.gondii oocysts in the soil of elementary public schools from the northwest area of the state of Sao Paulo. Our research group noted that $\mathrm{T}$. gondii oocysts are widely distributed on the soil of elementary public schools in our region, likely constituting the main contamination source for these children (Santos et al., 2010).

As daily routine, the cleaning of catteries, with removal of fecal material is indicated, since, in dependence on the environmental conditions, the T.gondii oocysts eliminated by cats, require at least 24 hours to sporulate and become infectious.It is also important to cover or encircle sand tanks for children recreation, especially when they are not in use, to prevent the access of cats [Bresciani et al. 2013].

The efficiency of a program that involves changes in lifestyle are associated with knowledge of the epidemiological aspects of the region, the standardization of service protocols, the establishment of a consensual ideal conduct and with technical support (Lopes-Mori et al., 2011), broad and repeated disclosure of actions highlighting the risk factors and the participation of all health professionals, pregnant women, family and community (Navarro et al., 2013).

Educational programs focused on reducing reducing environmental contamination by $\mathrm{T}$. gondii would reduce the cost of human treatment with clinical toxoplasmosis [santos, bresc].

\section{Conclusion}

Based on the obtained data, it is possible to infer that there is the need of implanting a community education program directed to the improvement of basic concepts of toxoplasmosis control and prevention.

\section{References}

[1] Kawazoe , U. Toxoplasma gondii. In: Neves D. P. Parasitologia Humana. 10 ed. São Paulo: Atheneu, 2002; p. 147-156.

[2] Rey, L. Toxoplasma gondii Toxoplasmose. Parasitologia. 4 ed. Rio de Janeiro: Guanabara Koogan, 2008, p 192-206.

[3] Bonametti, A. M.; Passos, J. N.; Da Silva, E. M. K.; Bortoliero, A.L. Surto De Toxoplasmose aguda transmitida através da ingestão de carne crua de gado ovino. Revista da Sociedade Brasileira de Medicina Tropical, Uberaba, v. 30, n. 1, p. 21-25, 1997.

[4] Lafferty, K. D. Look what the cat dragged in: do parasites contribute to human cultural diversity? Behavioural Processes, Amsterdam, v.68, n.3, p.279-282, 2005.

[5] Yolken, R. H.; Bachmann, S.; Rouslanova, I.; Lillehoj, E.; Ford, G.; Torrey, E. F.; Antiboidies to Toxoplasma gondii 
in individuals with first-episode schrizophrenia. Clinical Infection Disease, v. 32, n. 4, p. 842-844, 2001

[6] Hung, C.C.; Fan, C.K.; Su, K.E.; Sung, F.C.; Chiou, H.Y; Gil. V.; Ferreira, M.D.A. C.; Carvalho, J.M.; Cruz, C.; Lin, Y.K.; Tseng, L. F.; Sao, K.Y.; Chang, W. C.; Lan; H.S.; Chou, S.H. Serological screening and toxoplasmosis exposure factors among pregnant women in the Democratic Republic of Sao Tome and Principe. Transactions of the Royal Society of Tropical Medicine and Hygiene, v. 101, n.2, p. 134-139, 2007.

[7] Mitsuka-Breganó, R. Programa de Vigilância em Saúde da Toxoplasmose Gestacional e Congênita: elaboração, implantação e avaliação no município de Londrina, Paraná. Tese (Doutorado em Ciência Animal) - Universidade Estadual de Londrina, 2009.

[8] Bachmeyer, C.; Mouchnino, G.; Thulliez, P.; Blum, L. Congenital toxoplasmosis from an HIV-infected woman as a result of reactivation. The Journal of Infection, London, v.52, n.2, p.e55-e57, 2006.

[9] Jones, J. L. and Dubey, J. P. Foodborne Toxoplasmosis. Clinical Infectious Diseases, vol. 18, pp. 1-7. 2012.

[10] Dubey, J. P.; et al. Toxoplasmosis and neosporosis. In: Greene, C. E. Infectious diseases ofthe dog and cat.2.ed. Philadelphia: WB Saunders Company, 1998. Cap. 90, p.493-503.

[11] Frenkel, J. K.; A. Ruiz; M. Chinchilla. Soil survival of Toxoplasma oocysts in Kansas and Costa Rica. Am. J. Trop. Med. Hyg.,v. 24, 439-443, 1975.

[12] Garcia, L.C. Toxoplasma gondii. Diagnosis Medical Parasitology. 5th edition, A.S.M. Press, Washington, D.C.(USA). 2007, p 562-563.

[13] Dubey, J. P. Toxoplasmosis. Journal of the American Hospital Association, Schaumburg, v. 189, n. 2, p. 166-170, 1986

[14] Dubey, J.P.; Greene, C.E.; Lappin, M.R. Toxoplasmosis and neosporosis. In: Greene, C. E. Infectious diseases of the dog and cat. Philadelphia. W. B. Saunders, p. 818-834, 1990 .

[15] Dubey, J. P. Toxoplasmosis. Journal of the American Veterinary Medical Association, v. 205, n. 11, p. 1593-1598, 1994.

[16] Tenter, A. M.; Heckeroth, A. R.; Weiss, L. M. Toxoplasma gondii: from animals to humans. International Journal for Parasitology; v.30, p.1217-1258, 2000.

[17] Frenkel, JK.; Parker, BB. An apparent role of dogs in the transmission of Toxoplasma gondii . The probable importance of xenosmophilia. Annals of the New York. Academy of Sciences, New York, v.791, p.402-407, 1996.

[18] Lindsay, DS.; Dubey, JP.; Butler, JM.; Blagburn, BL. Mechanical transmission of Toxoplasma gondii oocysts by dogs. Veterinary Parasitology, Amsterdam, v.73, n.1/2, p.27-33, 1997

[19] Schares, G.; Pantchev, N.; Barutzki, D.; Heydorn, A. O.; Bauer, C; Conraths, FJ. Oocysts of Neospora caninum,
Hammondia heydorni, Toxoplasma gondii and Hammondia hammondi in faeces collected from dogs in Germany. International Jounal forParasitology, Oxford, v.35, n.14, p.1525-1537, 2005.

[20] Bresciani, K. D. S.; Toniollo, G. H.; Costa, A. J.; Sabatini, G. A.; Moraes, F. R. Clinical, parasitological and obstetric observations in pregnant bitches with experimental toxoplasmosis. Ciência Rural, Santa Maria, v.31, n.6, p.1039-1043, 2001.

[21] Monteiro, S.. G. Parasitologia na Medicina Veterinária, São Paulo: Roca, 2010, pp. 148-150.

[22] Okusaga, O. et al. Toxoplasma gondiiantibody titers and history of suicide attempts in patients with schizophrenia. Schizophrenia Research, v. 133, p. 150-155, 2011.

[23] Tomé, R.O., Serrano, A.C.M., Nunes, C.M. Perri, S.H.V.; Bresciani, K.D.S. Inquérito epidemiológico sobre conceitos de zoonoses parasitárias para professores de escolas municipais do ensino infantil de Araçatuba-SP. Revista Ciência em Extensão. vol.2, pp.38, 2005.

[24] Lima, F.F., Koivisto, M.B., Perri, S.H.V., Bresciani, K.D.S $\mathrm{O}$ conhecimento de idosos sobre parasitoses em instituições não governamentais do Município de Araçatuba, SP. Revista Ciência em Extensão, vol.4, pp. 77-85, 2008.

[25] Neto, L.C., Lima, F.F.L., Perri, S.H.V., Koivisto, M.B., Bresciani, K.D.S. Programa de conscientização de idosos sobre posse responsável de animais de estimação em bairro periférico do município de Araçatuba, SP. Revista Ciência em Extensão, v.7, n.2, p. 102-109, 2011.

[26] Bresciani, K. D. S.; Coelho, W. M. D.; Soubhia, A. M. P.; Koivisto, M. B. UNATI - Programa de Orientação sobre o controle de sanidade em pequenos animais para Terceira Idade, 2012.

[27] Greene, C. E. Infectious diseases of the dog and cat. Philadelphia: W. B. Saunders, 1990. p.819-829.

[28] Santos, T.R., Nunes, C.M., Luvizotto, M.C.R., Moura, A.B., Lopes, W.D.Z., Costa, Alvimar J.C., Bresciani, K.D.S. Detection of Toxoplasma gondii oocysts in environmental samples from public schools. Veterinary Parasitology, vol. 171, pp. 53-57, 2010.

[29] Bresciani, K. D. S.. Galvão, A.L.B., Vasconcellos, A.L., Silveira Neto, L., Inácio, S.V., Soares, J.A., Gomes, J.F., Santos, T.R., Santos, R.R. Toxoplasmosis in public health. Toxoplasma gondii: Prevalence in Humans and Animals, Genetic Structure and Role in Disease Distribution. Editora: Nova Publishers, New York, 2013.

[30] Lopes-Mori, F. M. R.; Mitsuka-Breganó, R.; Capobiango, J. D.; Inoue, I. T.; Reiche, E. M. V.; Morimoto, H. K. et al. Programas de controle da toxoplasmose congênita. Rev. Assoc. Med. Bras.[online]. 2011, vol.57, n.5, pp. 594-599.

[31] Navarro, I.T., Breganó, R.M., Mori, F.M.R.L., Rodrigues, T.O., Santos, T.R., Santos, R.R., Bresciani, K. D. S.. Control Program of Congenital Toxoplasmosis. Toxoplasma gondii: Prevalence in Humans and Animals, Genetic Structure and Role in Disease Distribution Editora: Nova Publishers, New York, 2013. 